\title{
Crop Depredation by Birds in Deccan Plateau, India
}

\author{
Manoj Ashokrao Kale, ${ }^{1}$ Nandkishor Dudhe, ${ }^{2}$ Raju Kasambe, ${ }^{3}$ and Prosun Bhattacharya ${ }^{1}$ \\ ${ }^{1}$ Department of Sustainable Development, Environmental Science and Engineering, KTH Royal Institute of Technology, \\ Teknikringen 76, 10044 Stockholm, Sweden \\ ${ }^{2}$ Environment Service Scheme (ESS), Centre for Environment Education (CEE), Pune 411 007, India \\ ${ }^{3}$ IBA-IBCN, Bombay Natural History Society, Mumbai 400023, India \\ Correspondence should be addressed to Manoj Ashokrao Kale; kmanoj@kth.se
}

Received 12 May 2014; Revised 11 August 2014; Accepted 13 August 2014; Published 3 September 2014

Academic Editor: Alexandre Sebbenn

Copyright (C) 2014 Manoj Ashokrao Kale et al. This is an open access article distributed under the Creative Commons Attribution License, which permits unrestricted use, distribution, and reproduction in any medium, provided the original work is properly cited.

Extent of crop depredation in agricultural fields of groundnut, pearl millet, peas, sorghum and sunflower was assessed in Pune, Akola and Amravati, the three productive districts of Maharashtra, India. The study included interviews with the farmers, identification of the bird species responsible for the crop depredation and actual field assessment of damage. The problem of crop depredation is severe for the crops mostly during harvesting season. Most farmers were not satisfied with the conventional bird repelling techniques. A maximum depredation was observed by Sorghum crops by house sparrows Passer domesticus, baya weavers Ploceus philippinus, and rose-ringed parakeets Psittacula krameri, accounting to $52 \%$ of the total damage. Blue rock pigeons Columba livia damaged $42 \%$ of the peas crop (chick peas and pigeon peas), while house sparrows and baya weaver damaged the groundnut crop by $26 \%$ in the sampling plots. House sparrow Passer domesticus and baya weaver Ploceus philippinus damaged the groundnut crop in the sampling plots just after the sowing period. The sustainable solution for reducing crop depredation is a need for the farmers and also such techniques will help avoid direct or indirect effects of use of lethal bird control techniques on bird species.

\section{Introduction}

Wide varieties of arable crops attract granivorous birds which lead to significant damage to the crop yields globally $[1,2]$. However, there are few studies pertaining to the awareness of the problem among the farmers and the magnitude of crop damage caused by the birds in India [3]. The problem of crop damage by birds is faced by the farmers and the losses due to crop depredation by birds are significant in terms of the gross crop yield. Birds can inflict damage to the crops and a loss to the farmers in all the stages of crops right from sowing and planting till harvesting.

In previous study conducted in India, it was found that the proportion of crop damage to sunflower crop depends on the proportion of foraging activity of the birds [4]. The food of the cropland species is of mostly three types which depend on grains, seeds, fruits, green vegetation of the crop plants and grasses, insects, other arthropods, and rodents found in the soil, crops, and other plants [5].

Most of the activities of birds are either advantageous or disadvantageous to the farmers. Birds create negative impact on most of the agricultural activities and some agricultural activities attract birds as special feeding opportunities [2]. The presence of insectivorous birds in croplands is beneficial to farmers up to some extent. In India, as a common remedy to the problem, attempts are regularly being made by the famers to reduce crop losses from birds by deploying measures for control of birds either through traditional means or by using bird scaring techniques, devices, and pesticides (Table 1).

The greatest damage to the matured crops was observed due to the foraging activities of bird species like Baya Weavers, Ploceus philippinus, and Munias, Lonchura spp., and House Crows, Corvus splendens, with an overall reduction of crop yield by more than 55\% [6]. Foraging pattern of birds depends on behavior of predator avoidance and not the status of feeding source [4]. In addition to these species of birds, the Rose-ringed Parakeet, Psittacula krameri, is the most common and destructive bird from agricultural perspective which inflicts huge damage to standing cereal crops, fruit orchards, and vegetable crops [7]. A single Rose-ringed Parakeet, Psittacula krameri, consumes about $15 \mathrm{~g}$ of sunflower seeds per day. Birds like Common Myna Acridotheres tristis, 
TABLE 1: Traditional and conventional bird scaring techniques deployed by farmers in India.

\begin{tabular}{lc}
\hline Techniques & Reference \\
\hline The white cloth banging & Kiruba et al. (2006) [11] \\
Chemical bird repellents are like trimethacarb, methiocarb, and curb & Bruggers et al. (1986) [12] \\
Killing and catching of birds & Singh and Dungan (1955) [13] \\
Methiocarb (4 methylthio) 3,5-xylyl-N-methyl carbamate, and Thiram & Sandhu (1987) [14] \\
Poisonous chemical & Bhatnagar (1976) [15] \\
\hline
\end{tabular}

Jungle Myna, Acridotheres fuscus, Brahminy Starling, Sturnus pagodarum, House Crow, Corvus splendens, and Whitecheeked Bulbul Pycnonotus leucotis damage the fruit crops especially of grapes to a great extent in Himachal Pradesh, India [8]. Not only are these damages limited to loss of yield but they also affect the quality of grapes which in turn reduces the quality of the wine [9]. Thus, birds cause a decrease in overall agricultural productivity. In Gujarat, Sarus Crane (Grus antigone) is considered one of the pests by farmers and it causes damage in the range of 0.2 to $13.6 \%$ to the paddy crops [10]. It is a globally threatened species and it was found that its population is declining at an alarming rate.

Agriculture is one of the important sectors of economic development of the state of Maharashtra. The total area under cultivation in Maharashtra is approximately $2.3 \mathrm{M}$ ha, out of which 80 to $85 \%$ has arable type of farming, whereas $16 \%$ of the area has horticultural farming, where many types of food grains, vegetables, and fruits are produced (http://www.mahaagri.gov.in). This paper presents the representative opinion on the prevailing awareness among the farmers about crop damage caused by birds and the current measures undertaken by them to reduce such damages. The study also assesses the damage to the common crops caused by cropland birds in Maharashtra, through systematic field studies.

\section{Material and Methods}

2.1. Study Area. The study was conducted in three agricultural productive districts, Pune $\left(18.53^{\circ} \mathrm{N}, 73.84^{\circ} \mathrm{E}\right)$, Akola $\left(20.50^{\circ} \mathrm{N}, 77.16^{\circ} \mathrm{E}\right)$, and Amravati $\left(20.93^{\circ} \mathrm{N}, 77.75^{\circ} \mathrm{E}\right)$ in the state of Maharashtra, which included interviews with the farmers, identification of the birds responsible for the loss of crop, and field assessment of crop loss. The questionnaire survey was conducted in two field campaigns: first during the harvesting season in winter 2010 and again the following winter in 2011. Damage assessment study was conducted in 2011 and 2012 in crop fields of groundnut, pearl millet, peas (chick peas and pigeon peas), sorghum, sunflower, and wheat, which are most common crops in the study area. The selected croplands in Pune district had irrigation facility, whereas the croplands in Akola and Amravati are located in rainfed region.

2.1.1. Questionnaire Survey and Interview. A questionnaire survey was designed with an aim to understand the current status of awareness among the farmers about the crop damage caused by birds in agricultural fields, methods for control of damage undertaken by them, and the opinion of farmers on the need for modern ecofriendly bird scaring techniques.

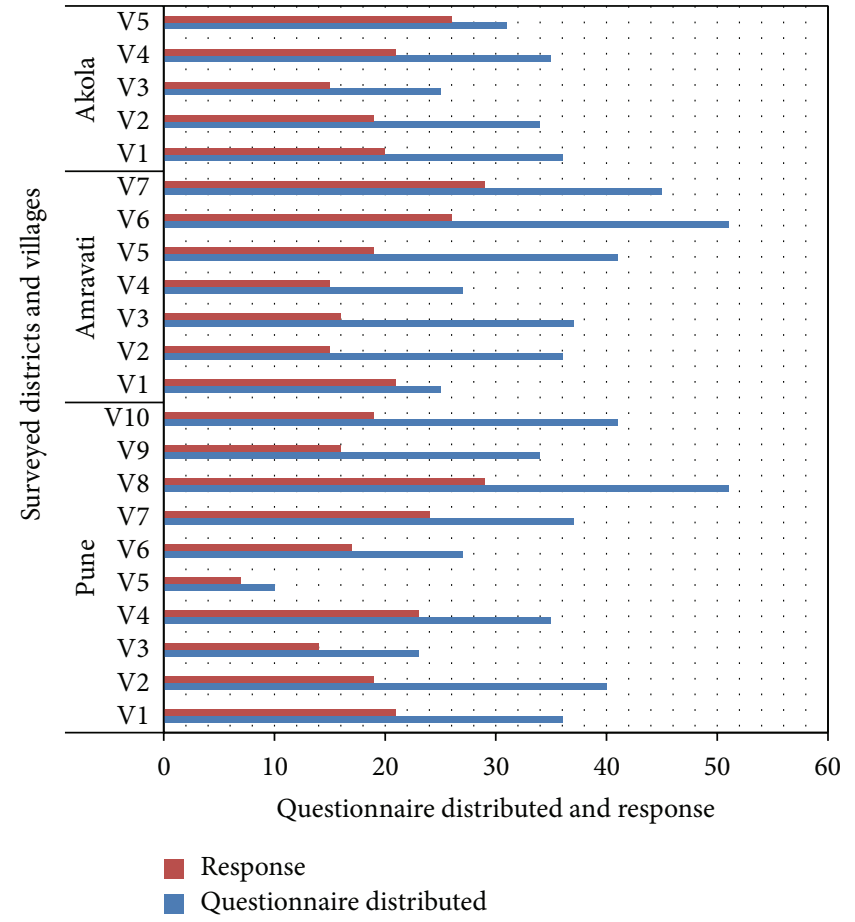

FIGURE 1: Frequency of the distribution of questionnaire to the farmers in the 22 villages in the study areas, and their responses.

The survey was conducted in 22 villages in three districts of Pune, Amravati, and Akola in Maharashtra state, where the questionnaires were distributed to 757 farmers (who actually worked in the farms during these seasons): 334 in Pune, 262 in Amravati, and 161 in Akola districts (Table 2). This survey was conducted after the harvesting season, except for the groundnut, in which case the survey was carried out during the sowing season. The overall response rate was $58 \%$ from the farmers (Figure 1).

2.2. Field Studies. In order to assess the crop damage in a field, we considered two important parameters - the size of the plot and location of the plot. We selected the plots at the edges of the field as well as in the interior, since we expected more variability for all crops in terms of growth and damage. Birds are commonly attracted at the edges of crop fields as compared to the interior for most of the crops. It is also important to apply proper bias during plot selection by avoiding individual bias during the plot selection process. The sampling design adopted for each field was delineation of 8 plots, from the interior and along the edges each of $1 \mathrm{~m}^{2}$ size (Figure 2). The total damage is estimated as an average of 
TABLE 2: Questionnaire survey response rate in different villages.

\begin{tabular}{|c|c|c|c|c|c|}
\hline District & Village & Questionnaire distributed & Response & Response rate & Survey period \\
\hline \multirow{10}{*}{ Pune } & $\mathrm{V} 1$ & 36 & 21 & 58 & Winter 2010 \\
\hline & V2 & 40 & 19 & 48 & Winter 2010 \\
\hline & $\mathrm{V} 3$ & 23 & 14 & 61 & Winter 2010 \\
\hline & V4 & 35 & 23 & 66 & Winter 2010 \\
\hline & V5 & 10 & 7 & 70 & Winter 2010 \\
\hline & V6 & 27 & 17 & 63 & Winter 2010 \\
\hline & V7 & 37 & 24 & 65 & Winter 2010 \\
\hline & V8 & 51 & 29 & 57 & Winter 2010 \\
\hline & V9 & 34 & 16 & 47 & Winter 2010 \\
\hline & V10 & 41 & 19 & 46 & Winter 2010 \\
\hline \multirow{7}{*}{ Amravati } & $\mathrm{V} 1$ & 25 & 21 & 84 & Winter 2011 \\
\hline & $\mathrm{V} 2$ & 36 & 15 & 42 & Winter 2011 \\
\hline & V3 & 37 & 16 & 43 & Winter 2011 \\
\hline & V4 & 27 & 15 & 56 & Winter 2011 \\
\hline & V5 & 41 & 19 & 46 & Winter 2011 \\
\hline & V6 & 51 & 26 & 51 & Winter 2011 \\
\hline & V7 & 45 & 29 & 64 & Winter 2011 \\
\hline \multirow{5}{*}{ Akola } & $\mathrm{V} 1$ & 36 & 20 & 56 & Winter 2011 \\
\hline & $\mathrm{V} 2$ & 34 & 19 & 56 & Winter 2011 \\
\hline & V3 & 25 & 15 & 60 & Winter 2011 \\
\hline & V4 & 35 & 21 & 60 & Winter 2011 \\
\hline & V5 & 31 & 26 & 84 & Winter 2011 \\
\hline
\end{tabular}

damages recorded at the edges and interior. In this study, 352 plots $((8$ interiors +8 edges $) \times 22$ fields for each crop) were selected for estimation of the damage and the data was collected from 2112 plots covering all six varieties of crops.

Visual techniques were adopted for damage estimation, which was initially applied for each plot. Digital camera enabled photographs (photographs from both the sides) of damaged crops were taken in each plot, to attain the degree of accuracy in the results of visual estimation following the methods developed by Martin and Crabb [16] and Tracey and Saunders [17]. For most of the crops, the accurate time of recording was close to the harvesting period, except in the case of groundnut, in which case the loss was recorded just after the sowing.

2.3. Damage Assessment. Damage assessment was carried out following the survey protocol which was used to collect data from each cropland. Visual estimation of damage in selected plots for each crop and the percentage of crop damage were calculated graphically for each plot and then overall damage for each crop field was calculated for edge and interior (Figure 2). Finally, average damage for each crop field was calculated as the average of edge and interior damage:

$$
\begin{aligned}
\text { Total damage in } \% & =\frac{D_{\text {edges }}+D_{\text {interior }}}{2} \\
& =D_{\text {edges }}=\frac{D_{e}}{D_{e}+D_{n e}}, \\
D_{\text {interior }} & =\frac{D_{i}}{D_{i}+D_{n i}},
\end{aligned}
$$

where $D_{e}$ is \% damage in crops on edge, $D_{n e}$ is \% of undamaged crops on interior plot, $D_{i}$ is \% damage of interior crop, and $D_{n i}$ is $\%$ of undamaged crops at interior areas. Consider

$$
D_{e}=\text { Edge damage }=\sum \frac{P_{i}}{N}
$$

where $i=1$ to 8 ; $N$ : total number of plots;

$$
D_{i}=\text { Interior damage }=\sum \frac{P_{i}}{N},
$$

where $i=1$ to 8 ; $N$ : total number of plots.

\section{Results and Discussion}

3.1. Awareness of Crop Damage Perceived by the Farmers. Outcomes of questionnaire survey reveal that the maximum number of farmers was aware of the loss of crop due to birds and most of them expressed that there is a need for a sustainable solution to control crop damage caused by birds (Figure 3). Farmers from all 3 districts expressed that problem of birds is temporary but severe for the crops and grains and for fruits, as the problems persist for longer time. All the farmers accept that they are using some kind of traditional bird scaring techniques to avoid the loss and this use is for effective time interval in which damage by birds is predicted. Most of the farmers were not satisfied with the conventional bird scaring techniques being used by them due to their less effectiveness and nonreliable nature and as it requires continues hard work and more man power. The 


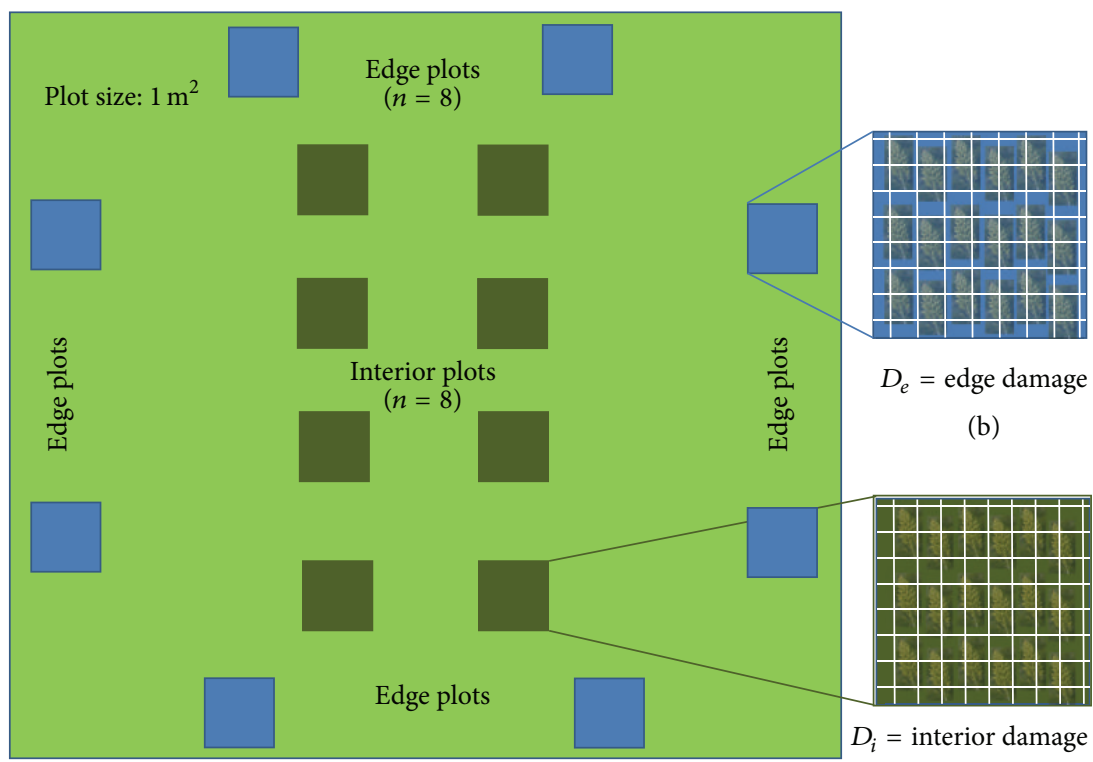

(a)

(c)

FIGURE 2: Schematic diagram illustrating the methodology adopted for the assessment of damage of crops. (a) Position of the edge plots and the interior plots and estimation of (b) edge damages and (c) interior damage through graphical technique.

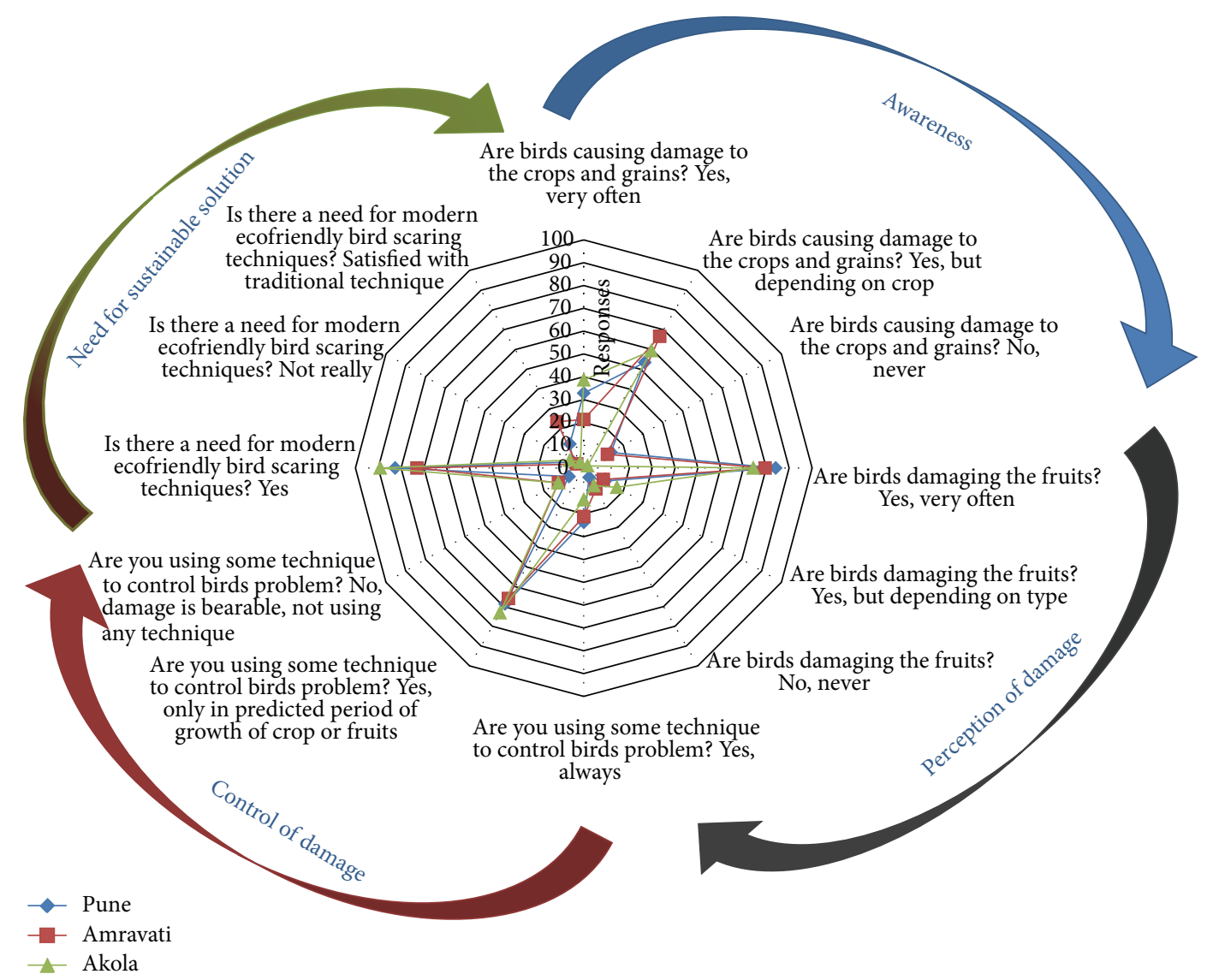

FIGURE 3: Responses of the farmers to the survey questionnaire following the studies in winter 2010 and 2011 in Akola, Amravati, and Pune districts of Maharashtra, India. 
techniques like use of chemical repellent, net, spike guards, shooting the birds with gunshot, and making loud noise by bursting fire crackers in order to scare birds are either costly or lethal. Farmers believed that present traditional techniques are not effective enough to control this loss and they also expressed the need for sustainable techniques which can replace the traditional bird scaring techniques and help them to reduce their loss more effectively in a sustainable way. Traditional methods are like "trial and error method," and bird species become habitual for such techniques and hence they did experience "scaring" from such techniques for longer time. It was also observed during field visits that birds were not afraid of bird scaring devices and it was also a common experience of farmers. Lethal techniques may be an effective solution to the problem but by killing birds we may be destroying one of the important bioindicators in the nature.

3.2. Assessment of Crop Damage. Agricultural loss of crops starts from sowing to harvesting stage due to abundance of cropland bird species for foraging (Figure 4(a)-4(c)). In most of the crops, the loss was considerably large at the edges of cropland primarily due to the presence of trees, bushes, and fencing along the edge [18]. In our study, we found that sorghum crop damage at interior was more as compared to edges (Figure 5). This variation in edge to interior depends on factors like size of crop and the environment surrounding the cropland. Sometimes damage in interior is more pronounced as compared to the edge when crop field is adjacent to the road [17]. Cropland birds damaging the crops are foraging in large flocks and most of the time they select the interior areas which result in large damage in interior [19]. For foraging, cropland birds tend to select a "test" area for damage, which they continue to graze again and again till the food of that area gets exhausted before moving on to a new area [20].

In our study, we found that more damage was inflicted in interior as compared to edges in the sorghum and pearl millet crops, as birds like the longer crop plants for secure feeding (Figure 4(a)). The foraging activities of cropland bird species like House Crow have caused more damage to wheat, while pigeons and doves cause damage to pearl millet and sunflower. Also, the parakeets and crows were found to inflict more damage to the crops than what they actually consumed. They carried parts of kernels of the Jowar with them and then fed on the grains. But, while feeding on the grains in this way, a major portion of the kernel with the grains falls down. A maximum loss is recorded to the sorghum crops by sparrows, weaver birds, and parakeets that accounts to 52\% (Figure 6). The minimum damage was recorded for wheat crop which was $17 \%$ and most of the damage was caused by crows, which was recorded on the site in Akola district. Pigeons damaged $42 \%$ of the peas crop (chick peas and pigeon peas) while sparrows and weaver birds damaged the groundnut crop by $26 \%$ in the sampling plots. The maximum damage to the pearl millet and sunflower was caused by sparrows and weaver birds mostly in Pune and Amravati. All the above bird species were recorded during more than $50 \%$ of the visits to the field. Cropland avian species recorded while causing damage to crops are given in Table 3.
TABLE 3: List of common birds in crop fields responsible for crop depredation in agricultural fields of Akola, Amravati, and Pune districts in Maharashtra state, India.

\begin{tabular}{lc}
\hline Species-common name (Latin name) & Status \\
\hline Asian Pied Starling (Sturnus contra) & $\mathrm{R}, \mathrm{O}$ \\
Ashy Prinia (Prinia socialis) & $\mathrm{R}, \mathrm{O}$ \\
Baya Weaver (Ploceus philippinus) & $\mathrm{R}, \mathrm{G}$ \\
Brahminy Starling (Sturnia pagodarum) & $\mathrm{R}, \mathrm{O}$ \\
Brown Rock Chat (Cercomela fusca) & $\mathrm{R}, \mathrm{I}$ \\
Black Drongo (Dicrurus macrocercus) & $\mathrm{R}, \mathrm{I}$ \\
Red-vented Bulbul (Pycnonotus cafer) & $\mathrm{R}, \mathrm{I}$ \\
Common Babbler (Turdoides caudata) & $\mathrm{R}, \mathrm{O}$ \\
Common Myna (Acridotheres tristis) & $\mathrm{R}, \mathrm{O}$ \\
Eurasian Collared Dove (Streptopelia decaocto) & $\mathrm{R}, \mathrm{G}$ \\
Green Bee-eater (Merops orientalis) & $\mathrm{R}, \mathrm{I}$ \\
House Crow (Corvus splendens) & $\mathrm{R}, \mathrm{O}$ \\
House Sparrow (Passer domesticus) & $\mathrm{R}, \mathrm{O}$ \\
Indian Roller (Coracias benghalensis) & $\mathrm{R}, \mathrm{I}$ \\
India Robin (Saxicoloides fulicatus) & $\mathrm{R}, \mathrm{I}$ \\
Oriental Magpie Robin (Copsychus saularis) & $\mathrm{R}, \mathrm{O}$ \\
Jungle Babbler (Turdoides striata) & $\mathrm{R}, \mathrm{O}$ \\
Jungle Prinia (Prinia sylvatica) & $\mathrm{R}, \mathrm{I}$ \\
Large Grey Babbler (Turdoides malcolmi) & $\mathrm{R}, \mathrm{O}$ \\
Laughing Dove (Spilopelia senegalensis) & $\mathrm{R}, \mathrm{G}$ \\
Plain Prinia (Prinia inornata) & $\mathrm{R}, \mathrm{I}$ \\
Plum-headed Parakeet (Psittacula cyanocephala) & $\mathrm{R}, \mathrm{G}$ \\
Rock Pigeon (Columba livia) & $\mathrm{R}, \mathrm{G}$ \\
Yellow-eyed Babbler (Chrysomma sinense) & $\mathrm{R}, \mathrm{O}$ \\
Rose-ringed Parakeet (Psittacula krameri) & $\mathrm{R}, \mathrm{G}$ \\
Red-wattled Lapwing (Vanellus indicus) & $\mathrm{R}, \mathrm{C}$ \\
\hline & $\mathrm{T}$ \\
\hline - &
\end{tabular}

R: resident species, F: Frugivore, O: Omnivore, I: Insectivore, G: Granivore.

These results are comparable with the previous study results in other agricultural states of India. For example, in Punjab which is one of the important agricultural hubs of India, considerable damage to the crops such as groundnut, maize, mustard, pearl millet, peas, sorghum, sunflower, and wheat is caused by certain bird species [3]. Damage for sorghum and sunflower is recorded maximum in Akola district and peas damage was more in Amravati district. Both of these districts are in rainfed farming zone.

The loss of peas was recorded mostly by pigeons while sorghum was damaged by sparrows, weaver birds, and parakeets. The groundnuts were damaged by sparrows and weaver birds just after the sowing. These birds can cause $10 \%$ to $40 \%$ damage and may cause $90 \%$ damage in isolated areas in the sunflower field where sunflower is an important edible oil seed crop.

\section{Conclusions}

The present study reveals that crop depredation by birds is a serious problem in the agricultural state of Maharashtra. The questionnaire survey also indicted that traditional bird scaring techniques were not very effective in controlling this 


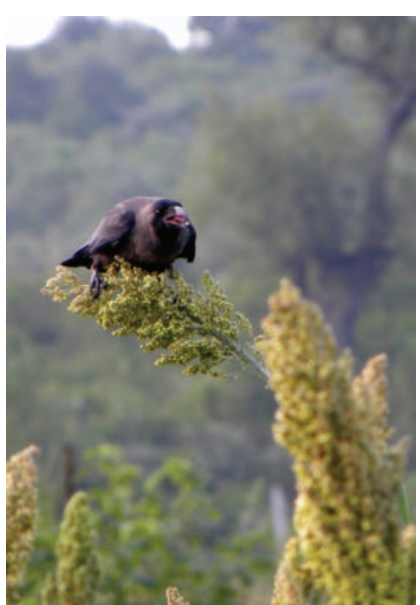

(a)

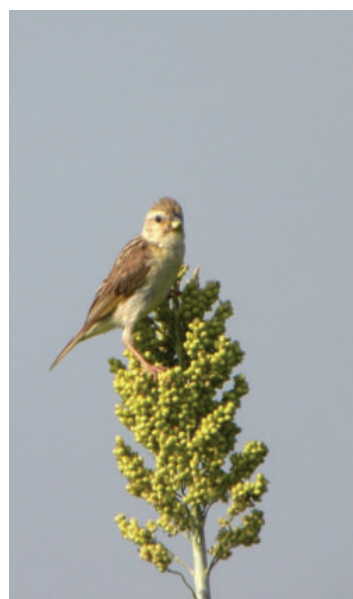

(b)

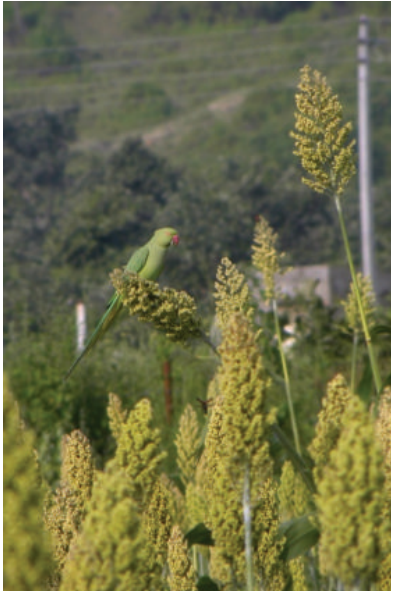

(c)

Figure 4: Photographs of the typical cropland bird species foraging on the sorghum millets. (a) House Crow, Corvus splendens, (b) Baya Weaver, Ploceus philippinus, and (c) Rose-ringed Parakeet Psittacula krameri in Amravati crop fields.

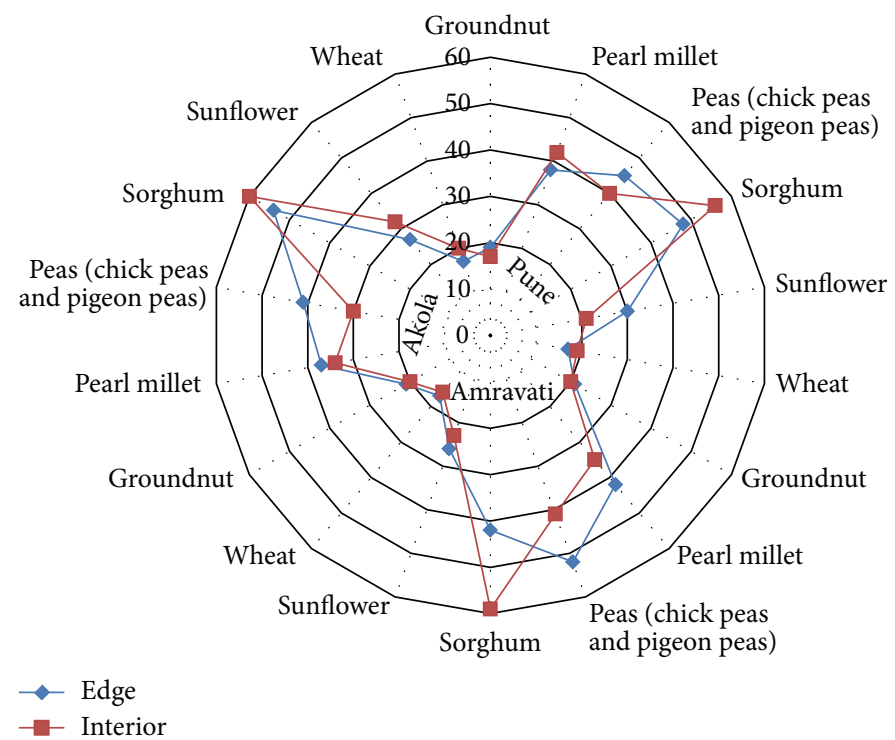

Figure 5: Radar diagram showing the extent of crop damage along the edges and the interior of the crop fields in the districts of Pune, Amravati, and Akola of Maharashtra state, India.

problem. The actual damage assessments of common crops in the three study sites indicate that Sorghum was the most affected crop due to depredation followed by pearl millet and combined chick peas and pigeon peas crops. The sustainable solution for reducing loss of crop is a need of the farmers and also such techniques will help to avoid direct or indirect effects of use of lethal bird control techniques on avian species. Though the area for this study was limited, it reveals the trends of agricultural loss due to birds. The problem of crop depredation should be study in larger agricultural area of the country and more concrete damage estimation should be done. Future work should focus on designing a sustainable solution by developing ecofriendly bird cropspecific and bird-specific scaring techniques to minimize crop depredation due to birds for improving the crop yields.

\section{Conflict of Interests}

The authors declare that there is no conflict of interests regarding the publication of this paper.

\section{Acknowledgments}

The authors are thankful to the farmers who allowed access to their croplands. The authors thank Mr. Gase, from Akola district (a farmer and teacher who received Best Farmer's Award by the Maharashtra state), for his help during the study. MK gratefully acknowledges the financial support from Erasmus Mundus External Cooperation Window (EMECW) and the Department of Sustainable Development, Environmental Science and Engineering, KTH Royal Institute of 


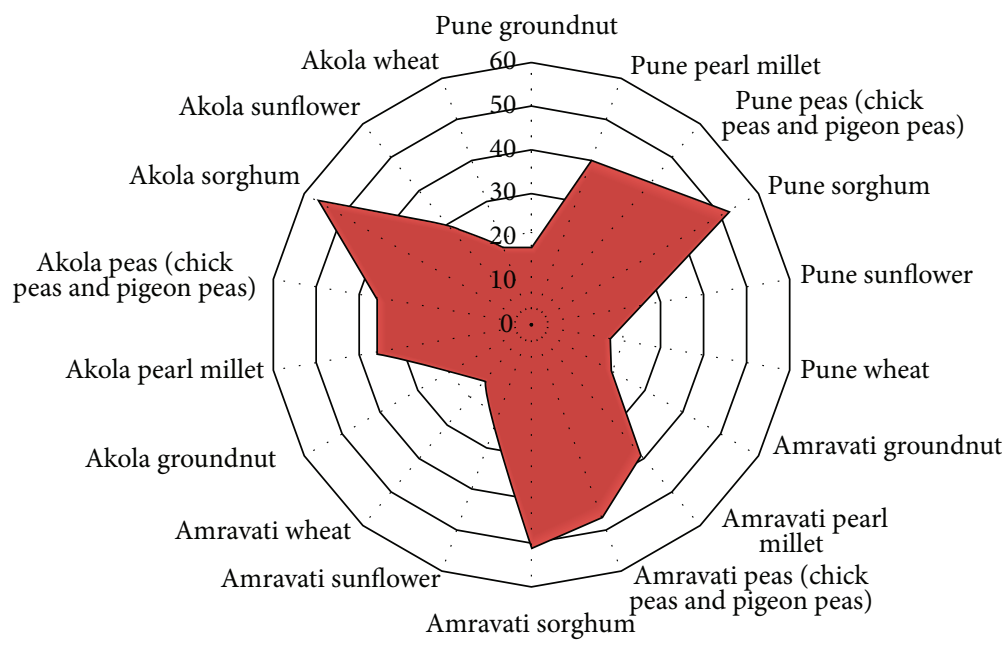

Crop loss

Figure 6: Radar diagram showing the average loss of individual crops due to bird depredation in Akola, Amravati, and Pune districts of Maharashtra state, India, during 2011 and 2012.

Technology, Stockholm, Sweden. The authors are thankful to the anonymous reviewers for their constructive comments and suggestions which have helped to improve the quality of the paper. The corresponding author is thankful to Professor Anna Ledin for her constant encouragements during the finalization of this paper.

\section{References}

[1] J. D. Coleman and E. B. Spurr, "Farmers'perception of bird damage and control in arable crop," New Zealand Plant Protection, vol. 54, pp. 184-187, 2001.

[2] S. J. Ormerod, E. J. P. Marshall, G. Kerby, and S. P. Rushton, "Meeting the ecological challenges of agricultural change: editors' introduction," Journal of Applied Ecology, vol. 40, no. 6, pp. 939-946, 2003.

[3] M. S. Dhindsa and H. K. Saini, "Agricultural ornithology: an Indian perspective," Journal of Biosciences, vol. 19, no. 4, pp. 391402, 1994.

[4] S. Subramanya, "Non-random foraging in certain bird pests of field crops," Journal of Biosciences, vol. 19, no. 4, pp. 369-380, 1994.

[5] R. J. O'Connor and M. Shrubb, Farming and Birds, Cambridge University Press, Cambridge, UK, 1986.

[6] R. L. Bruggers, E. Rodriguez, and M. E. Zaccagnini, "Planning for bird pest problem resolution: a case study," International Biodeterioration and Biodegradation, vol. 42, no. 2-3, pp. 173184, 1998.

[7] S. P. S. Kushwaha and P. S. Roy, "Geospatial technology for wildlife habitat evaluation," Tropical Ecology, vol. 43, no. 1, pp. 137-150, 2002.

[8] S. K. Patyal and R. S. Rana, "Bird damage to Kinnow fruits in 13 Himachal Pradesh and evaluation of management techniques against them," Pest Management and Economic Zoology, vol. 14, no. 1-2, pp. 157-161, 2006.

[9] C. Loinger, S. Cohen, N. Dror, and M. J. Berlinger, "Effect of grape cluster rot on wine quality," The American Journal of Enology and Viticulture, vol. 28, pp. 196-199, 1977.
[10] C. K. Borad, A. Mukherjee, and B. M. Parasharya, "Damage potential of Indian sarus crane in paddy crop agroecosystem in Kheda district Gujarat, India," Agriculture, Ecosystems and Environment, vol. 86, no. 2, pp. 211-215, 2001.

[11] S. Kiruba, B. Mishra, P. Israel, S. Stalin, S. Jeeva, and S. S. M. Das, "Traditional pest management practices in Kanyakumari district, southern peninsular India," Indian Journal of Traditional Knowledge, vol. 5, pp. 71-74, 2006.

[12] R. L. Bruggers, J. E. Brooks, R. A. Dolbeer et al., "esponses of pest birds to reflecting tape in agriculture," Wildlife Society Bulletin, vol. 14, no. 2, pp. 161-170, 1986.

[13] R. P. Singh and G. H. Dungan, "How to catch crows," Allahabad Farmer, vol. 29, pp. 59-67, 1955.

[14] P. S. Sandhu, M. S. Dhindsa, and H. S. Toor, "Evaluation of methiocarb and thiram as seed treatments for protecting sprouting maize from birds in Punjab (India)," Tropical Pest Management, vol. 33, pp. 370-372, 1987.

[15] R. K. Bhatnagar, "Significance of birds management and control," Pesticides, vol. 10, pp. 74-73, 1976.

[16] L. R. Martin and A. C. Crabb, "Preliminary studies of a bird damage assessment technique for trellised grapes," in Vertebrate Pest Control and Management Materials, technical publication 2, pp. 205-210, American Society for Testing Materials, Vertebrate Pest Control and Management Materials, 1979.

[17] J. Tracey and G. Saunders, Bird Damage to the Wine Grape Industry, Report to the Bureau of Rural Sciences, Department of Agriculture, Fisheries and Forestry, Vertebrate Pest Institute, NSW Agriculture, 2003.

[18] C. M. Somers and R. D. Morris, "Birds and wine grapes: Foraging activity causes small-scale damage patterns in single vineyards," Journal of Applied Ecology, vol. 39, no. 3, pp. 511-523, 2002.

[19] S. R. X. Dall, I. C. Cuthill, N. Cook, and M. Morphet, "Learning about food: Starlings, skinner boxes, and earthworms," Journal of the Experimental Analysis of Behavior, vol. 67, no. 2, pp. 181192, 1997. 
[20] R. W. DeHaven and R. L. Hothem, "Estimating bird damage from damage incidence in wine grape vineyards," American Journal of Enology and Viticulture, vol. 32, pp. 1-4, 1981. 

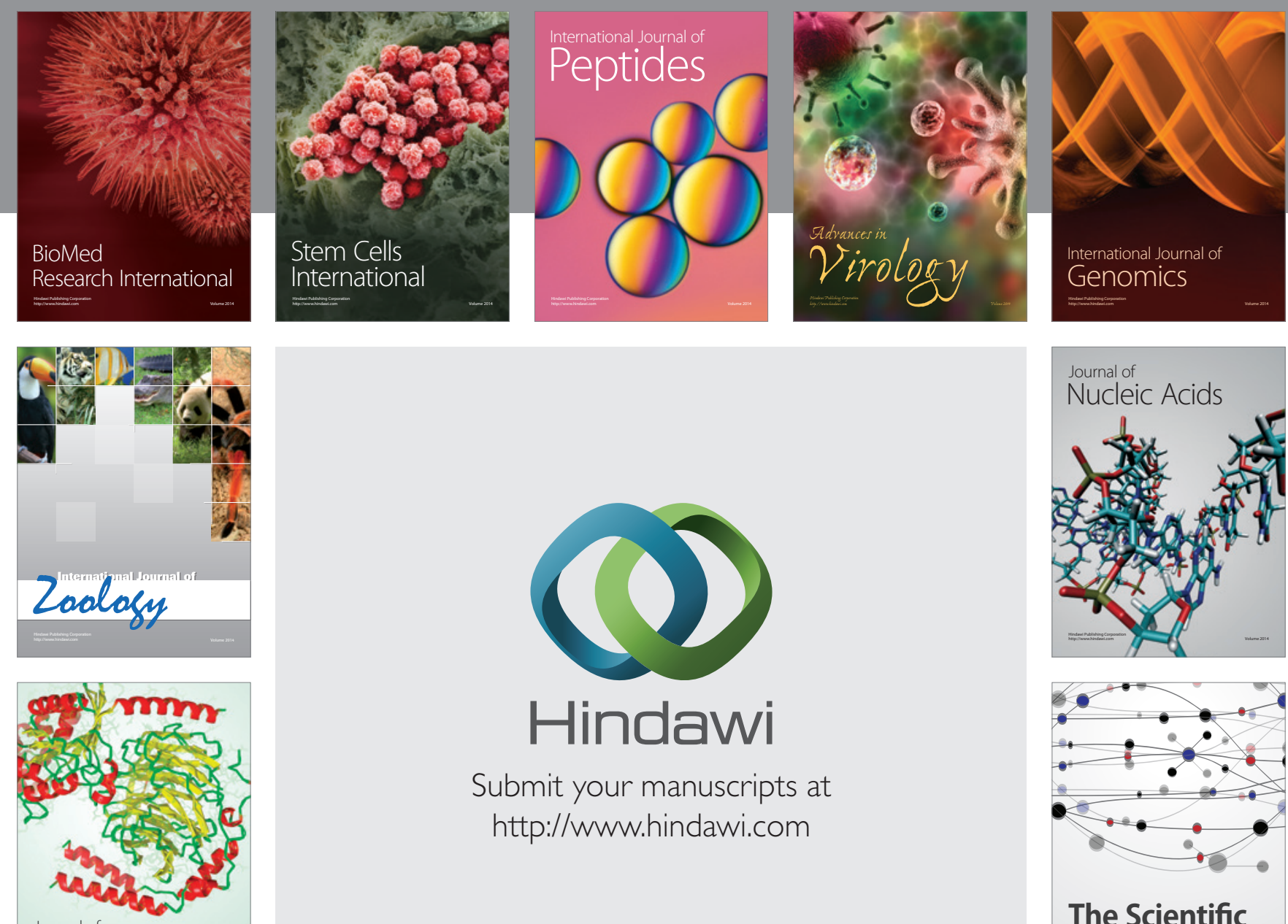

Submit your manuscripts at

http://www.hindawi.com

Journal of
Signal Transduction
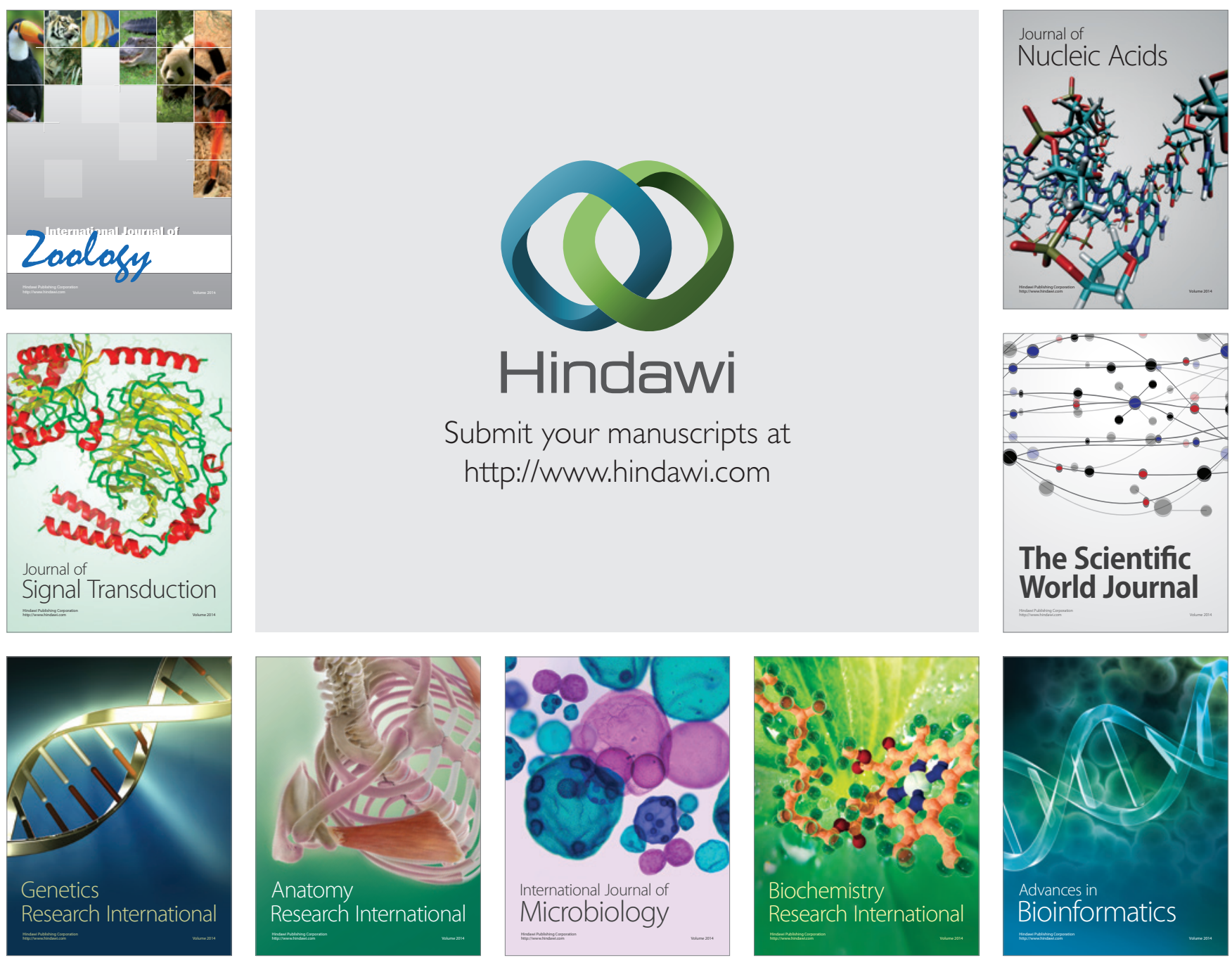

The Scientific World Journal
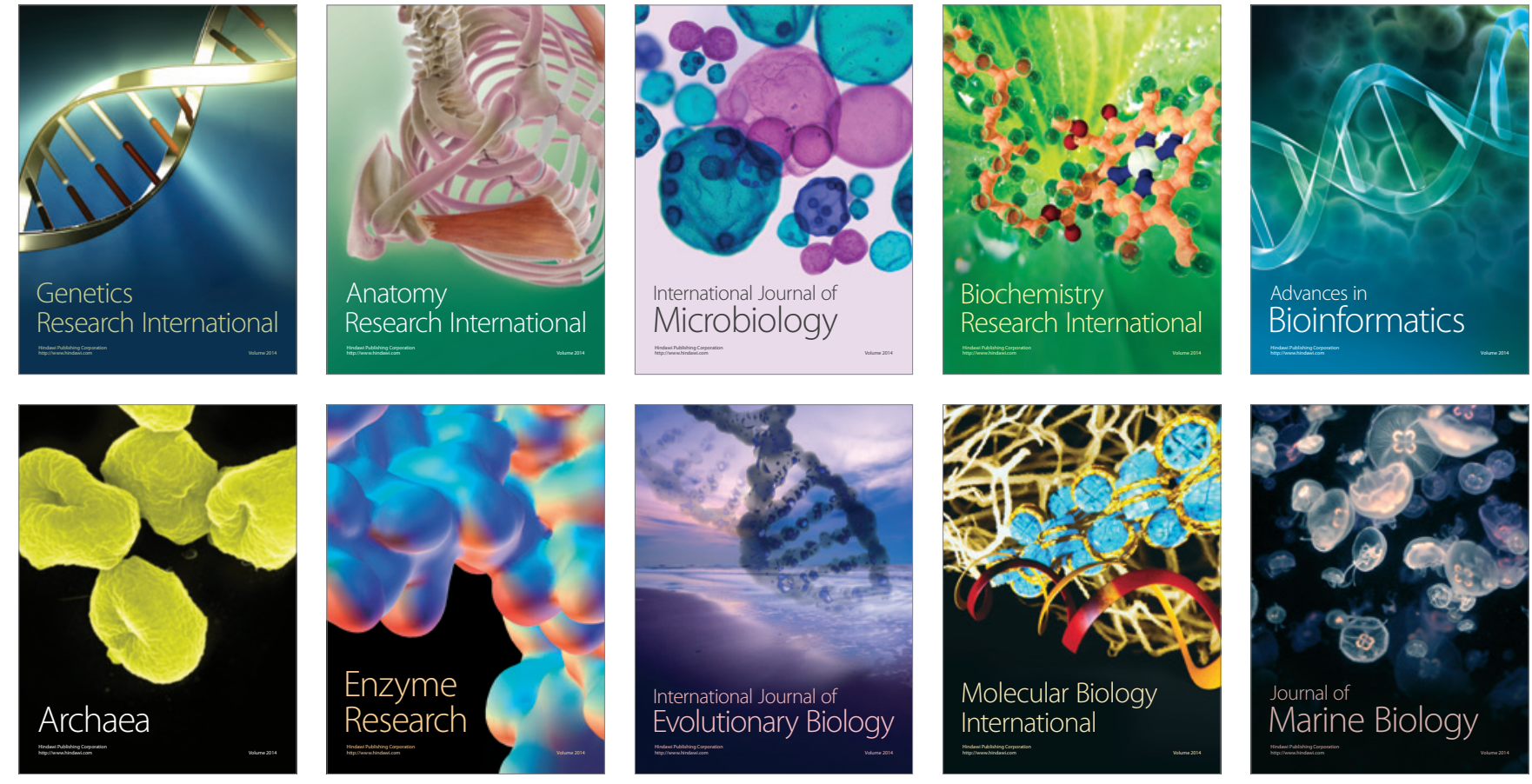